\title{
Contribution of dietary arginine to nitrogen utilisation and excretion in juvenile sea bass (Dicentrarchus labrax) fed diets differing in protein source
}

\author{
F. Tullia, ${ }^{a,}$, C. Vachot ${ }^{b}$, E. Tibaldi ${ }^{a}$, V. Fournier ${ }^{b}$ and S.J. Kaushik ${ }^{b}$ \\ a Dipartimento di Scienze Animali, via S. Mauro, 2, 33010 Pagnacco, UD, Italy \\ ${ }^{\mathrm{b}}$ Laboratoire de Nutrition des Poissons, Unité mixte INRA-IFREMER, Station d'Hydrobiologie, INRA, B.P. 3 , \\ 64310 St Pée sur Nivelle, France \\ *: Corresponding author : Tulli F., Tel.: +39 432 650110; fax: +39 432 660614, email address : \\ francesca.tulli@uniud.it
}

\begin{abstract}
:
The role of dietary arginine in affecting nitrogen utilisation and excretion was studied in juvenile European sea bass (Dicentrarchus labrax) fed for 72 days with diets differing in protein sources (plant protein-based (PM) and fish-meal-based (FM)). Fish growth performance and nitrogen utilisation revealed that dietary Arg surplus was beneficial only in PM diets. Dietary Arg level significantly affected postprandial plasma urea concentrations. Hepatic arginase activity increased $(P<0.05)$ in response to dietary Arg surplus in fish fed plant protein diets; conversely ornithine transcarbamylase activity was very low and inversely related to arginine intake. No hepatic carbamoyl phosphate synthetase III activity was detected. Dietary arginine levels did not affect glutamate dehydrogenase activity. A strong linear relationship was found between liver arginase activity and daily urea-N excretion. Dietary Arg excess reduced the proportion of total ammonia nitrogen excreted and
\end{abstract}


conversely increased the contribution of urea- $\mathrm{N}$ over the total $\mathrm{N}$ excretion irrespective of the dietary protein source. Plasma and excretion data combined with enzyme activities suggest that dietary Arg degradation via hepatic arginase is a major pathway for ureagenesis and that ornithine-urea cycle is not completely functional in the liver of juvenile sea bass.

Keywords: arginine, urea, arginase, excretion, sea bass, Dicentrarchus labrax,.

\section{Introduction}

The use of protein-rich plant ingredients such as soy protein derivatives, maize and wheat glutens has received increasing attention as potential substitutes for fish proteins in practical feeding of European sea bass (Ballestrazzi et al., 1994; Oliva-Teles et al., 1998; Tibaldi and Tulli, 1998; Tibaldi et al., 1998; Robaina et al., 1999; Tibaldi et al., 2003; 2004).

One of the major constraints which limits the substitution is the poor amino acid balance of plant proteins due to deficiencies or disproportionate levels of certain essential or non essential constitutive amino acids relative to the ideal dietary protein profile of this fish species. This can lead to reduced growth performance and nitrogen retention and in turn, to increased $\mathrm{N}$ waste being released into the environment.

As with other monogastric livestock there is evidence that supplementing plant protein-based diets with the limiting essential amino acid (EAA) results in improved intake, growth performance and $\mathrm{N}$ retention although this has not always given them a definite advantage over standard fish meal diets (Tibaldi et al., 2004) even if almost total replacement of fish meal by plant protein sources in the diet of sea bass has been obtained without adverse effects on growth or $\mathrm{N}$ utilisation (Kaushik et al., 2004). This suggests that supplementation of plant protein-based diets should not be limited only to the first limiting EAA and that should be given consideration to overall amino acid balance. After lysine, arginine is one of the most limiting EAA in certain protein-rich plant ingredients such as maize and wheat gluten. Hence supplementing diets, based largely on these ingredients, with arginine, might improve growth and nitrogen retention and conversely reduce $\mathrm{N}$ waste as a result of a better dietary amino acid balance.

There are other possible ways by which arginine supplementation could be beneficial in improving growth and nitrogen retention and these are not limited to plant protein diets. In salmonids, there is experimental evidence that arginine acts as secretagogue of insulin 
1 (Plisetskaya et al., 1991; Lall et al., 1994; Mommsen et al., 2001). Hence a large dietary

2 surplus of this amino acid might increase amino acid uptake by tissues through an insulin3 mediated mechanism. Surplus dietary arginine may also improve growth given its role as 4 secretagogue of growth regulating hormones (GH and IGF-1) (Forster, 1993; Lall et al., 5 1994). Arginine is also involved in urea production via the arginase pathway and/or OUC 6 cycle. Intraperitoneal injection of arginine in rainbow trout has been proven to modulate urea excretion (Kaushik et al., 1988) and more recently arginine degradation has been shown to be a major pathway in ureogenesis in turbot (Gouillou-Coustans et al., 2002).

The objectives of the present study were to investigate the effects of excess arginine in diets containing different proportions of fish and plant-protein sources on growth response and nitrogen gain and to elucidate the role of this amino acid in regulating $\mathrm{N}$ excretion in European sea bass.

\section{Materials and methods}

\subsection{Experimental diets}

We used five pelleted diets whose composition is shown in Table 1. The first basal diet $(\mathrm{F} 1)$ corresponded to a conventional formulation in which the major portion of nitrogen was derived from feed-grade fishery byproducts. It was supplemented with L-arginine to provide a moderate excess of this amino acid. The diet denoted as F2 was derived from the basal one with a further addition of crystalline L-arginine to increase its dietary surplus. A second basal diet (P1) was formulated so as to have almost all of nitrogen supplied by wheat gluten. It was supplemented with crystalline L-lysine and sulphur amino acid (SAA) to meet the theoretical EAA needs (Kaushik, 1998). The arginine level in diet P1 (1.6 g/100 g) was kept close to the optimal dietary level for this species (i.e. $1.8 \mathrm{~g} / 100 \mathrm{~g}$ in maize gluten based diets providing $7.4 \% \mathrm{~N}$, Tibaldi et al., 1994). The remaining two diets (P2 and P3) were based on diet P1 and crystalline L-arginine was added so that the dietary levels of this amino acid were the same as those supplied by diets F1 and F2. Apart from arginine, the EAA profile of the diets compared favourably with the amino acid profile of fish whole body (Kaushik, 1998). All diets were kept isonitrogenous (7.5\% DM) and L-arginine was supplemented in replacement of L-glutamic acid. 


\subsection{Feeding trial}

The feeding trial was conducted at the experimental facilities of the Dipartimento di Scienze Animali - University of Udine, Italy, in an indoor partial recirculating and thermoregulated seawater system consisting of fifteen $200 \mathrm{~L}$ fiberglass tanks. During the experiment water temperature, salinity and flow rate were set at $24 \pm 1{ }^{\circ} \mathrm{C}, 34 \mathrm{~g} / \mathrm{l}$ and 3 $\mathrm{l} / \mathrm{min} /$ tank respectively. Water $\mathrm{pH}$ and dissolved oxygen level were measured daily and averaged $7.7 \pm 0.1$ and $7.0 \pm 0.1 \mathrm{mg} / \mathrm{l}$ while total ammonia nitrogen (TAN) and nitrite $\left(\mathrm{N}-\mathrm{NO}_{2}\right)$ concentrations were monitored weekly and averaged $0.04 \pm 0.001 \mathrm{mg} / \mathrm{l}$ and $0.01 \pm 0.005$ $\mathrm{mg} / \mathrm{l}$ respectively. Additional fluorescent lighting was supplied to provide a constant $12 \mathrm{D}: 12$ $L$ regime.

Juvenile European sea bass (Dicentrarchus labrax) were obtained from a commercial hatchery (Panittica Pugliese, Torre Canne, Italy) and were sorted by size. Fish groups, each consisting of 45 sea bass juveniles (initial mean body weight: $8.5 \mathrm{~g}$ ), underwent a preliminary 15-day adaptation period before being fed the experimental diets. Each diet was then given for 72 days to triplicate groups of fish according to a completely random design. Feeds were offered to apparent satiety (visual observation of first feed refusal) in three meals per day (8 a.m., 12 a.m, 4 p.m). At the beginning and at the end of the experimental period and every two weeks throughout the trial, fish were group-weighed under moderate anaesthesia (MS222) after an overnight fast. Feed consumption and mortality were recorded daily.

\subsection{Sampling}

The comparative slaughter technique was adopted for evaluating changes in whole body composition and measuring nitrogen gain in fish subjected to the different dietary treatments. Whole body composition was determined on a pooled sample of ten fingerlings at the beginning and on pools of five fish per tank at the end of the growth trial. Specimens for whole body analysis were sacrificed using an excess of anaesthetic (MS222) and were kept frozen until analysis.

At the end of the growth trial, blood and liver samples were taken from randomly selected fish at 0 and $6 \mathrm{~h}$ after the morning meal in order to measure plasma levels of $\mathrm{N}$ catabolites (total ammonia, urea, uric acid) and the activity of liver enzymes involved in the ornithine-urea cycle (OUC): carbamoyl phosphate synthetase III (CPS III, EC 2.7.2.9), ornithine transcarbamoylase (OCT, EC 2.1.3.3), arginase (ARG, EC 3.5.3.1) or which initiate 
1 amino acid catabolism: glutamate dehydrogenase (GDH, EC 1.4.1.2). Five fish per tank for 2 each sampling time were sacrificed by a blow on the head. Livers were rapidly removed, 3 weighed and frozen in liquid nitrogen until analyzed. Blood samples $(0.5 \mathrm{ml})$ were taken from caudal vessels using heparinized syringes. After centrifugation (3000 x g, $10 \mathrm{~min}$.) plasma was stored at $-20{ }^{\circ} \mathrm{C}$ until analyzed. Five individual samples were collected from each tank for each sampling time, for plasma ammonia, urea and uric acid determinations.

\subsection{Excretion trials}

Measurements of total ammonia and urea-nitrogen excretions were carried out in a thermoregulated $\left(23 \pm 0.2^{\circ} \mathrm{C}\right.$ ), UV-treated, marine (salinity $34 \mathrm{~g} / \mathrm{l}$ ) closed system consisting of 6 tanks (individual capacity $55 \mathrm{I}$ ) designed according to the original layout described by Cho et al. (1982). Tanks were each stocked with 30 fish (1.52 $\pm 0.2 \mathrm{~kg}$ total biomass) randomly selected from those remaining in each dietary group at the end of the growth trial. A 4-week adaptation period during which each fish-group was fed the corresponding diet in a single meal (0.9 - 1\% body weight), preceded the measurements.

Two 24-hour Nexcretion cycles at 8-day intervals were performed for each diet in duplicate tanks. Inlet and outlet water samples were taken regularly from each tank every 2 hours after a single meal (calculated to equalize $\mathrm{N}$ intake of the five dietary groups) to measure total ammonia and urea- $\mathrm{N}$ concentrations. In each cycle one tank without any fish was used for measuring blank values. The water of the system was totally replaced with pretreated marine water the day preceding each measurement. Calculations of TAN and urea-N excretions were carried out according to Kaushik (1980).

\subsection{Analytical methods}

The diets and freeze-dried fish pool sampled for the analysis of whole body composition were ground and analyzed for proximate composition according to AOAC (1980) methods. Nutrient gains and retention efficiencies were calculated.

Total ammonia in plasma was determined spectrophotometrically after enzymatic $(\mathrm{GDH})$ reaction using a commercially available kit (Sigma 171-a). Plasma urea was measured on deproteinized samples (TCA 3\%) with diacetylmonoxime according to Aminot 
and Kerouel (1982). Uric acid level in the plasma was assayed after reaction with uricase using a commercial diagnostic kit (Sigma 684).

Water ammonia and urea concentrations were measured spectophotometrically according to Solorzano (1969) and Aminot and Kerouel (1982).

The activities of the OUC enzymes and GDH were assayed on the same liver sample in duplicate according to Brown and Cohen (1959) and Bergmeyer (1974) with some modifications (Gouillou-Coustans et al., 2002). For each sample and OUC enzyme assay, a blank without substrate was treated under the same conditions to take into account non enzymatic urea or citrulline formation during assay. All the enzymes were characterized in terms of kinetic parameters according to Lineaweaver-Burk. The enzyme activity was expressed as ?mol product per total liver weight per $100 \mathrm{~g}$ whole body weight as suggested by Cowey (1995) to study the effect of dietary treatments. The protein content of the extracts was determined according to Bradford (1976) using bovine serum albumin as a standard.

\subsection{Statistical analyses}

All the response parameters observed or calculated were subjected to one-way analysis of variance to assess the effect of dietary treatment and, if appropriate, the means were compared using the Duncan's multiple range test (Snedecor and Cochran, 1989). Statistical comparison among means was carried out at a significance level of $5 \%$.

\section{Results}

\subsection{Growth performance and efficiency}

Mortality was negligible throughout the trial (5 fish out of 675 stocked) and there were no evidence of outward pathological signs in fish fed diets differing in protein source or arginine level. The final weight and voluntary intake of dry matter, nitrogen and arginine of juvenile sea bass are presented in Table 2. Fish readily accepted the plant-protein based diets and no differences were found due to protein source or dietary arginine level, in the overall DM or $\mathrm{N}$ intakes scaled by the average body weight calculated the end the trial.

Sea bass fed the fish meal based diets attained similar final mean live weights and they were higher than those of fish fed the plant protein-based diets $(P<0.05)$. Among the 
1 latter, sea bass fed the diet with marginally limiting arginine level (P1) had a lower live

2 weight than fish fed diets P2 and P3 (28.1 vs $32.4 \mathrm{~g}, P<0.05)$ which did not differ from each other.

A large excess of arginine in the feed had no appreciable effect on feed efficiency and PER values in fish fed fish meal-based diets (Table 2). On the contrary, both parameters improved in response to a moderate surplus of dietary arginine in sea bass fed the plant protein-based diets (P2 vs $P 1, P<0.05$ ) while a larger dietary excess of this amino acid (diet P3) did not further improve feed and protein efficiencies (P3 vs P2, P>0.05).

As shown in Table 3, whole body protein content was affected by dietary treatments with a lower value in fish fed diet $\mathrm{P} 1$ in comparison to the other diets $(P<0.05)$ thus reflecting the lower $\mathrm{N}$ gain and retention measured with this diet. Whole body lipid levels were not influenced by the diet.

Lipid gain was not affected by dietary treatments while $\mathrm{N}$ gain and retention efficiency were lower in fish fed the diet with marginally limiting arginine levels than in those fed fish protein-based diets (P1 vs F1, F2, $P<0.05$ ). Both a moderate and a large arginine excess in plant-protein diets (P2 and P3) resulted in a marked improvement of both parameters which did not differ from those exhibited by fish fed diet F2.

Liver to body weight ratio (HSI) was affected by dietary treatments and a large excess of dietary arginine resulted in a significant reduction of $\mathrm{HSI}$ for both fish meal and plant protein based diets. Supplying arginine at a marginal level (P1) led to a significant increase in hepatosomatic index value in comparison to the adequate level (2.8 vs $2.2, P<0.05)$. Mesenteric fat to body weight ratio (MF) in fish fed the plant protein based diets was significantly affected by the dietary arginine level with the highest value in fish fed diet P2 (8.44 vs $6.68, P<0.05)$.

\subsection{Liver enzymes activity}

A preliminary investigation was carried out to assess the presence of the activity of carbamoyl phosphate synthetase III (CPS III) considered to be a key enzyme in urea formation through the OUC. Measurements were run in parallel with ones of a mouse liver (as a mammalian model known to have high CPS I activity) using different substrates and activators or inhibitors to avoid potential interferences with CPS activities other than CPS III. The assays showed expression of CPS I activity with a mitocondrial location in the mouse liver extract while no measurable CPS III activity was found in the liver of the sea bass. Two 
1 other liver enzymes of the OUC (arginase - ARG and ornithine transcarbamoylase - OCT)

2 as well as glutamate dehydrogenase-GDH, which plays an important role in amino acid

3 transdeamination as a major pathway of ammoniogenesis in fish, were characterized for the 4 kinetic parameters listed in Table 4.

Data on liver ARG, OCT and GDH activities in sea bass fed the experimental diets are shown in Figures 1, 2, and 3. Hepatic arginase activities were of the same magnitude either just before the meal or 6-h after feeding. Six hours after feeding, arginase activity was higher in sea bass fed fish meal based diets than in those fed plant protein diets. The arginase activity increased in response to increased arginine intake in the liver of fish fed the plant protein based diets ( $\mathrm{P} 1$ vs $\mathrm{P} 2$ vs $\mathrm{P} 3, P<0.05)$, while no such changes in response to a large surplus of arginine were observed in fish given diet F2 compared to those fed diet F1 (Figure 1). Hepatic OTC activity decreased significantly with increasing Arg intake 6-h after the meal irrespective of dietary protein source (Figure 2). Similar trend was not apparent in pre-feeding conditions. Hepatic GDH activity (Figure 3) was hardly affected by the dietary protein source or arginine intake except for a significant increase in fish fed diet F2 (4\% arg) 6-h after the meal while fish fed diet P2 (3\% arg) exhibited the highest value under prefeeding conditions $(P<0.05)$.

\subsection{Nitrogen catabolites in plasma}

Data analysis revealed no interaction between sampling time (pre-feeding $(0 \mathrm{~h})$ or $6 \mathrm{~h}$ after a single meal) and dietary treatment relative to plasma parameters. Table 5 shows that, regardless of dietary treatment and as expected from previous investigations, total ammonia and urea concentrations in plasma were significantly higher $6 \mathrm{~h}$ post-feeding in comparison with those measured just before the meal. Plasma uric acid levels were not affected by the blood sampling time.

The effect of dietary treatments on plasma total ammonia and urea levels are shown in Figures 4 and 5 respectively. Plasma ammonia nitrogen was not affected by dietary treatments under pre-feeding conditions while 6-hours post-feeding fish fed diet P1 exhibited the lowest plasma ammonia nitrogen concentration $(P<0.05)$ (Figure 4).

As shown in Figure 5, fish fed the diet with marginal arginine level (diet P1) had the lowest plasma urea concentration 6-h after the meal $(P<0.05)$. Under a moderate or a large excess of dietary arginine there was an increase in plasma urea levels irrespective of the dietary protein source. Under pre-feeding conditions, plasma urea concentrations were low in 
1 all dietary groups except in those fed diet $\mathrm{P} 1$. The dietary treatments did not significantly

\subsection{Ammonia and urea excretion}

The daily pattern of total ammonia and urea excretions of sea bass fed the different diets are presented in Figures 6 and 7. The pattern of total ammonia excretion was similar for the 5 diets with peak levels reaching 6 hours post-feeding followed by decreasing values approaching almost prefeeding rates $24 \mathrm{~h}$ after the meal. The urea- $\mathrm{N}$ excretion profiles also did not show major differences in pattern among the five dietary treatments. As shown in Table 6, total $\mathrm{N}$ excretion of sea bass (as the sum of TAN plus Urea-N) did not differ among dietary groups and ranged between 42 and $47 \%$ of the ingested nitrogen.

The absolute values of total daily ammonia excretion were not significantly affected by dietary treatments, although higher values $(+10 \%)$ were noted in fish fed the plant-protein diets. However when expressed as percentage of $\mathrm{N}$ intake, TAN excretion was lower in fish fed the fish meal based diets compared to those given plant-proteins as a major $\mathrm{N}$ source with extreme values for diets $\mathrm{P} 1$ and $\mathrm{P} 2$ respectively $(P<0.05)$. A large surplus of dietary arginine in plant protein-based diets tended to reduce ammonia excretion (\% of $\mathrm{N}$ intake) to values comparable to those measured in sea bass fed fish protein-based diets. Both absolute and relative (as \% of $\mathrm{NI}$ ) values of daily urea-N excretion were affected by dietary treatment resulting in the lowest value in fish fed diet $\mathrm{P} 1(P<0.05)$ in comparison with the other dietary groups. Sea bass fed fish or plant protein-based diets exhibited a similar tendency of increasing urea- $\mathrm{N}$ excretion in response to increasing levels of supplemental dietary arginine and strong linear relationships were found when mean values of the $6 \mathrm{~h}$ arginase activity $(r=0.89, n=5 . P<0.01)$ and daily urea- $N$ excretion $(r=0.97, n=5 . P<0.01)$ were plotted against arginine intake irrespective of the diet being offered (Figure 8).

\section{Discussion}

Irrespective of dietary arginine levels, replacing a substantial amount of fish meal with plant protein in diets where major EAA limitations were removed by supplementation with crystalline amino acids, resulted in lower growth sea bass in comparison to those fed fish meal based diets as it was observed for other carnivorous species (Hardy, 1996). As corn gluten and wheat gluten meal are known to be highly digestible in sea bass (Tulli et al., 2004) 
1 and are relatively poor in antinutritional factors such an effect can be ascribed partly to

2 reduced voluntary feed intake (Dias et al., 1997) and partly to reduced biological value of the dietary protein (Rérat, 1971). The fish of the present experiment did not suffer reductions in voluntary feed intake as an adequate supplementation of feeding stimulant in the form of fish meal protein was included in the plant protein-based diets used here and our own previous data have shown that even high levels $(70 \%)$ of substitution of fish meal with wheat gluten did not reduce palatability nor nitrogen utilisation (Tibaldi et al., 2003). The reduction in growth performances and $\mathrm{N}$ utilisation could probably be related to the lower IAA profile (EAA index value) and consequent reduced biological value of the plant protein-based diets relative to the fish meal ones even if there was no EAA deficiency per se. The IAA imbalances and bioavailabilities due to the presence of corn and wheat gluten meals affected overall biological value for sea bass juveniles.

A dietary surplus of arginine in sea bass fed the high gluten diets proved to be beneficial in improving growth and markedly improved $\mathrm{N}$ gain and retention efficiency but it was ineffective in juvenile sea bass fed fish protein as the main $\mathrm{N}$ source. Hence, based on growth response, dietary arginine excess revealed no apparent somatotropic effects in sea bass. In juvenile Pacific salmon and rainbow trout, Plisetskaya et al. (1991) reported a transient growth enhancement caused by feeding a large surplus of arginine. A slight, but not significant, improvement of growth in response to moderate arginine surplus has been reported in some studies on arginine requirement of salmonids (Walton et al., 1986; Cho et al., 1992; Lall et al., 1994). In contrast, an increase in dietary arginine level up to $4 \%$ resulted in adverse effects on the growth of rainbow trout (Fournier et al., 2003). Moreover the adverse effects of disproportionate amounts of lysine and arginine described in higher animals (Harper et al., 1970; Southern and Baker, 1982) was not evident in sea bass juveniles here. Similar results were observed in a previous study were sea bass, similar to some warmwater teleosts (Nose 1979; Robinson et al., 1981), appeared apparently insensitive to a moderate dietary excess of arginine as well a to disproportionate levels of lysine (Tibaldi et al., 1994).

In general, there was no correlation between plasma total ammonia concentration and total or free glutamate intake while urea formation appeared directly influenced by dietary arginine level. Indeed we observe here that it increased substantially once the dietary requirement level was met (Tibaldi et al., 1994). Similar results were recently observed in rainbow trout and turbot (Fournier et al., 2003). The plasma urea trend observed $6 \mathrm{~h}$ post feeding agrees with our earlier findings on the response of peak (6 hour post feeding) plasma urea concentration to excess dietary arginine in sea bass (Tibaldi et al., 1995). 
The expression and activity of liver enzymes involved in the ornithine-urea cycle (OUC), as a major pathway in ammonia detoxification and urea formation in teleosts, has been questioned frequently (Huggins et al., 1969; Dépèche et al., 1979; Mommsen and Walsh, 1991; Wright et al., 1995; Wright and Land 1998). There was no measurable activity of hepatic CPS III and this observation is in agreement with earlier data from channel catfish (Anderson and Walsh, 1995), rainbow trout (Chiu et al., 1986; Todgham et al., 2001) and turbot (Gouillou-Coustans et al., 2002). Although Chiu et al. (1986) detected a very low activity of hepatic CPS, they concluded that the results were not consistent with the role of OUC as an ammonia detoxifying mechanism. Despite the absence of a functional CPS III, significant OCT activity was measured in sea bass liver. The conservation of functional OCT has already been observed in channel catfish (Wilson, 1973) and more recently in turbot and rainbow trout (Fournier et al., 2003) and in the muscle of African tilapia growing in an alkaline lake (Lindley et al., 1999). The decrease in liver OCT activity with increasing dietary arginine intake suggests a negative control of arginine on OCT activity. These observations appear consistent with the hypothesis of the involvement of liver OCT in de novo synthesis of arginine as sea bass as well as turbot and rainbow trout exhibited no arginine requirement for maintenance (Fournier et al., 2002).

In contrast to OCT, whose kinetic parameters were quite low, liver arginase activity was found to be very high and this observation confirms earlier data of Corti et al. (1985) and Dosdat et al. (1996) in this species and in general agrees with what is known for most teleosts where arginase is the only enzyme of the OUC being present in significant amounts in the liver (Cowey and Walton, 1989). Similar to the results observed by Berge et al. (1997) in Atlantic salmon, liver arginase activity in sea bass responded to increasing levels of dietary arginine. The strong relationship between arginine intake, arginase activity and urea $\mathrm{N}$ excretion all confirms that dietary arginine plays an important role in modulating arginine catabolism as well as urea synthesis and excretion in this fish species and that liver OUC in sea bass is probably not completely functional as in other Teleosts (Mommsen and Walsh, 1991; Fournier et al., 2003).

As with most carnivorous fish species, the kinetic parameters of GDH revealed high potential amino acid catabolic activity in sea bass. The values obtained here fall in the same range of values $(1.4-3.7 \mathrm{mM})$ reported for strictly carnivorous Teleosts such as rainbow trout and tuna (Cowey and Walton, 1989). Many studies carried out under a variety of dietary conditions have shown that carnivorous fish species lack adaptive response in the activities of enzymes such as GDH, which initiate amino acid catabolism (Cowey and Walton, 1989). However, most research in this field has dealt with diets with extreme protein levels. To date, 
1 the effects of disproportionate dietary levels of single amino acids on the activity of amino acid-catabolizing enzymes and particularly on GDH have received little or no attention. It is tempting to speculate that increased liver GDH activities in fish fed diets with a large surplus of a single amino acid, as in the present experiment, could be a consequence of a dietary amino acid imbalance, induced by excessive dietary arginine which in turn stimulated amino acid catabolism in the liver. This assumption apparently seems inconsistent in this study because increased liver GDH activities in fish fed excessive arginine were not coupled with a concurrent rise in plasma ammonia or total ammonia excretion (see Figure 5 and Table 7). Similarly, Kim et al. (1987) observed that rainbow trout liver GDH activity was not influenced by tryptophan level or protein source in the diet. The results concerning the GDH activity, together with measurements of plasma ammonia levels and ammonia excretion in response to the dietary treatments, were less clear and suggest the need for further studies to investigate the effects of manipulating dietary amino acid levels and balance on other pathways of ammonia formation (purine nucleotide cycle) as well as the contribution of organ and tissues other than the liver to ammonia production.

The daily patterns of ammonia and urea excretion observed in the present trial closely fit those reported by other authors for sea bass fed a single meal under a wide range of body sizes and dietary conditions (Ballestrazzi et al., 1994; 1998; Dosdat et al., 1996; Robaina et al., 1999). As already noted by Dosdat et al. (1996) urea excretion in sea bass did not reveal peak levels although it tended to be higher during the first 10 hours after the meal. Total $\mathrm{N}$ excretion was only marginally affected by the dietary protein source or arginine level in sea bass fed a single meal at equalized $\mathrm{N}$ intake. Depending on the diet, urea- $\mathrm{N}$ represented a variable proportion of total N-excretion (from 8.2 to $21.0 \%$ ) and accounted for 3.6 to $9.2 \%$ of the nitrogen intake. Such figures fall within the range of values reported by Dosdat et al. (1996) for sea bass of two size classes (10 and $100 \mathrm{~g}$ ) fed a fish protein diet supplying $8.3 \%$ $\mathrm{N}($ TAN + urea-N 43-47 \% NI, Urea-N, $13 \%$ of total N excretion or 5-6\% NI). Interestingly, a large excess in dietary arginine tended to reduce the proportion of $\mathrm{N}$ excreted as ammonia and conversely increased the contribution of urea- $\mathrm{N}$ over the total $\mathrm{N}$ excretion irrespective of the dietary protein source. Similar to our results, higher levels of ammonia excretion in sea bass fed diets in which fish meal was partially replaced by maize or wheat gluten were found in previous studies (Ballestrazzi et al., 1994; Robaina et al., 1999). This was explained by extensive deamination of glutammic acid and other amino acids which are present in disproportionate amounts in plant protein sources. Such an effect could have been further enhanced in the present study by adding glutammic acid to the diets to make them isonitrogenous. However possible explanations of the effects of dietary amino acid imbalance 
or disproportions remain somewhat speculative as TAN excretion with the different diets did not correlate with the corresponding measurements of liver GDH activity in this study.

\section{Conclusion}

In sea bass juveniles the utilisation of plant protein ingredients such as wheat gluten and corn gluten meal can be enhanced by the supplementation of dietary arginine but excess of dietary arginine did not lead to any improvement in nitrogen gain or growth. In addition, the results of the present study confirm the direct implication of dietary arginine in urea formation and excretion in sea bass and that arginolysis appears to be directly influenced by arginine intake and only partially by degradation of body arginine.

\section{Acknowledgements}

We would like to thank Dr. D. Bianco and Dr. S. Cabiddu (University of Udine) for their help with the chemical analysis. The research was funded by the European Union under the FAIR program (CT98-3408).

\section{References}

Aminot A. and Kerouel R., 1982. Dosage automatique de l'urée dans l'eau de mer: une methode trés sensible à la diacétylmonoxime. Can. J. Fish. Aquat. Sci. 39: 174-183.

Anderson P.M. and Walsh P.J., 1995. Subcellular localisation and biochemical properties of the enzymes of carbamoyl phosphate and urea synthesis in the bathrachoidid fish Opsanus beta, Opsanus tau and Porichthys notatus. J. Exp. Biol., 198: 755-766.

AOAC, 1980. In : Horwitz, W (Ed.), Official Methods of Analysis A.O.A.C., $13^{\text {th }}$ edn. Association of Analytical Chemists, Washington, DC, $1018 \mathrm{p}$.

Ballestrazzi R., Lanari D., D’Agaro E., Mion A., 1994. The effect of dietary protein level and source on growth, body composition, total ammonia and reactive phosphate excretion of growing sea bass (Dicentrarchus labrax). Aquaculture 127 : 197-206.

Ballestrazzi R., Lanari D., D'Agaro E., 1998. Performance, nutrient retention efficiency, total ammonia and reactive phosphorus excretion of growing European sea bass (Dicentrarchus labrax) as affected by diet processing and feeding level. Aquaculture 161: 55-65.

Berge G.E., Lied E., Sveier H., 1997. Nutrition of Atlantic salmon (Salmo salar): the requirement and metabolism of arginine. Comp. Biochem. Physiol. A 117: 501-509.

Bergmeyer H.U., 1974. Methods of enzymatic analysis. 4: 1704-1708.

Bradford M.M., 1976. A rapid and sensitive method for the quantification of microgram quantities of protein utilising the principle of protein-dye binding. Anal. Biochem. 72: 248254.

Brown G.W. and Cohen P.P., 1959. Comparative biochemistry of urea synthesis. 1- Methods for quantitative assay of urea cycle enzymes in liver. J. Biol. Chem., 234: 1769-1774.

Chiu Y.N., Austic R.E., Rumsey G.L., 1986. Urea cycle activity and arginine formation in rainbow trout (Salmo gairdnerI). J. Nutr. 116: 1640-1650. 
Cho C.Y., Slinger S.J., Bayler H.S., 1982. Bioenergetic of salmonid fish: energy intake, expenditure and productivity. Comp. Biochem. Physiol., 73B: 25-41.

Corti A., Astancolle S., Davalli P., Piccinini G., Casti A., Viviani R., 1985. Poliamine ed enzimi della loro biosintesi in Dicentrarchus labrax. Oebalia 11 Special Issue: 85-92.

Cowey C. B. and Walton M.J., 1989. Intermediary Metabolism,. In «Fish Nutrition », J.E. Halver ed., pp259-329. Academic press, Inc., San Diego (USA).

Cowey C.B., 1995. Protein and amino acid requirements: a critique of methods. J. Applied Ichthyology 11: 199-204.

Dèpéche J., Gilles R., Daufresne S., Chiapello H., 1979. Urea content and urea production via the ornithine-urea cycle pathway during the ontogenic cevelopment of two teleost fishes. Comp. Biochem. Physiol. A 63: 51-56.

Dias J., Gomes E., Kaushik S.J., 1997. Improvement of feed intake through supplementation with an attractant mix in European seabass fed plant protein rich diets. Aquat. Living Resour., 10: 385-389.

Dosdat A., Servais F., Metailler R., Huelvan C., Desbruyeres E., 1996. Comparison of nitrogenous losses in five teleost fish species. Aquaculture 141: 107-127.

Forster JP., 1993. Arginine requirement of juvenile rainbow trout (Oncorhynchus mykiss). $\mathrm{PhD}$. Thesis University of Washington, $117 \mathrm{pp}$.

Fournier V., Gouillou-Coustans MF., Metailler R., Vachot C., Moriceau J., Le Delliou H., Huelvan C., Desbruyeres E., Kaushik S.J., 2002. Nitrogen utilisation and ureogenesis as affected by dietary nucleic acid in rainbow trout (Oncorhynchus mykiss) and turbot (Psetta maxima). Comp. Biochem. Physiol., 26: 177-188.

Fournier V., Gouillou-Coustans, MF., Metailler R., Vachot C., Moriceau J., Le Delliou H., Huelvan C., Desbruyeres E., Kaushik S.J., 2003. Excess dietar arginine affects urea excretion but does not improve $\mathrm{N}$ utilisation in rainbow trout Oncorhynchus mykiss and turbot Psetta maxima. Aquaculture 217: 559-576.

Gouillou-Coustans M.F., Fournier V., Metailler R., Vachot C., Desbruyères E., Huelvan C., Moriceau J., Le Delliou H., Kaushik S.J., 2002. Dietary arginine degradation is a major pathway in ureagenesis in juvenile turbot (Psetta maxima). Comp. Biochem. Physiol. A, 132 (2): 305-319.

Hardy R.W., 1996. Alternate protein sources for salmon and trout diets. Animal Feed Science and Technology, 59: 71-80.

Harper A.E., Benvenga N.J., Wohlhueter R.M., 1970. Effects of ingestion of disproportionate amounts of amino acids. Physiol. Rev., 50: 428-543.

Huggins A.K., Skutsch G., Baldwin E., 1969. Ornithine urea cycle enzyme in teleostean fish. Comp. Biochem. Physiol., 28: 587-602.

Kaushik S.J. 1980. Influence of nutritional status on the daily patterns of nitrogen excretion in the carp (Cyprinus carpio L.) and the rainbow trout (Salmo gairdneri R.). Reprod. Nutr. Dévelop. 20 (6) : 1751-1765.

Kaushik S.J. 1998. Whole body amino acid composition of European seabass (Dicentrarchus labrax), gilthead seabream (Sparus aurata) and turbot (Psetta maxima) with an estimation of their IAA requirement profiles. Aquat. Living Resour. 11 (5): 355-358.

Kaushik S.J., Fauconneau B., Terrier L., Gras J., 1988. Arginine requirement and status assessed by different biochemical indices in rainbow trout (Salmo gairdneri R.). Aquaculture 70: 75-97.

Kaushik S.J., Coves D., Dutto G., Blanc D., 2004. Almost total replacement of fish meal by plant protein sources in the diet of a marine teleost, the European seabass, Dicentrarchus labrax. Aquaculture 230: 391-404.

Kim K., Kayes T.B., Amundson C.H., 1987. Effects of dietary tryptophan levels on growth, feed/gain, carcass composition and liver glutamate dehydrogenase activity in rainbow trout (Salmo gairdneri). Comp. Biochem. Physiol., 88B: 737-741. 
Lall S.P., Kaushik S.J., Le Bail P.Y., Keith R., Anderson J.S., Plisetskaya E., 1994. Quantitative arginine requirement od Atlantic salmon (Salmo salar) reared in sea water. Aquaculture, 124: 13-21.

Lindley T.E., Scheiderer C.L., Walsh P.J., Wood C.M., Bergman H.L., Bergman A.L., Laurent P., Wilson P., Anderson P.M., 1999. Muscle as the primary site of urea cycle enzyme activity in an alkaline lake-adapted tilapia, Oreochromis alcalicus grahami. J. Biological Chem., 274: 29858-29861.

Mommsen T.P. and Walsh P.J., 1991. Urea synthesis in fishes: evolutionary and biochemical perspectives. In: Biochemistry and Molecular Biology of Fishes, (P.W. Hochachka P.W. and T.P. Mommsen Eds.). Vol. 1, pp.137-163.

Mommsen T.P., Moon T.W., Plisetskaya E.M., 2001. Effects of arginine on pancreatic hormones and hepatic metabolism in rainbow trout. Physiol. Biochem. Zool. 74: 668-678.

Nose T., 1979. Summary report on the requirement of the essential amino acids for carp. In: K. Tiews and J.E. Halver (Eds.), Finfish Nutrition and Fishfeed Technology, vol. 1. Heenemann, Berlin, pp. 145-156.

Oliva-Teles A, Pereira J.P., Gouveia A., Gomes E., 1998. Utilization of diets supplemented with microbial phytase by sea bass (Dicentrarchus labrax) juveniles. Aquat. Living Resour.,11: 255-259.

Plisetskaya E., Buchelli-Narvaez L.I., Hardy R.W., Dickhoff W.W., 1991. Effects of injected and dietary arginine on plasma insulin levels and growth of pacific salmon and rainbow trout. Comp. Biochem. Physiol., 98: 165-170.

Rérat A., 1971. La valeur biologique des proteines: quelques acquisitions récentes. AA.Zootech., 20: 193-246.

Robaina L., Corraze G., Aguirre P., Blanc D., Melcion J.P., Kaushik S. 1999. Digestibility, post-prandial ammonia excretion and selected metabolites in European sea bass (Dicentrarchus labrax) fed pelleted or extruded diets with or without wheat gluten. Aquaculture $179: 45-56$.

Robinson, E.H., Wilson, R.P., Poe, W.E., 1981. Arginine requirement and apparent absence of a lysine-arginine antagonism in fingerling channel catfish. J. Nutr., 111: 46-51.

Snedecor G. and Cochran W.G., 1989. Statistical Methods, $8^{\text {th }}$ edn. The lowa State University press, Ames, IA, $505 \mathrm{p}$.

Solorzano L., 1969. Determination of ammonia in natural waters by phenolhypoclorite method. Limnol. Oceanogr., 14: 799-801.

Southern L.L. and Baker D.H., 1982. Performance and concentration of amino acids in plasma and urine of young pigs fed diets with excess of either arginine or lysine. J. Anim. Sci., 55: 857-862.

Tibaldi E., Tulli F., Lanari D., 1994. Arginine requirement and effect of different dietary arginine and lysine levels for fingerling sea bass (Dicentrarchus labrax). Aquaculture, 127: 207218.

Tibaldi, E. , Tulli, F. , Lanari, D. 1995. A note on the use of plasma urea level to validate the arginine requirement assessed by growth data in seabass (Dicentrarchus labrax). J. Appl. Ichthyology, 11 (3/4): 297-301.

Tibaldi E. and Tulli F., 1998. Partial replacement of fish meal with soybean products in diets for juvenile sea bass (D. labrax). Proc. VIII Int. Symp. on Nutrition and Feeding of Fish. ( Eds.) Gran Canaria, Spain, June 1-4 : 149.

Tibaldi E., Tulli F., Dias Freire R., 1998. Alternative protein sources in diets for juvenile sea bass (Dicentrarchus labrax). Biologia Marina Mediterranea, 5(3) :2034-2043.

Tibaldi E., Tulli F., Piccolo G., Guala S., 2003. Wheat gluten as a partial substitute for fish meal protein in sea bass (D. labrax) diets. Ital. J. Anim. Sci., 2: 613-615.

Tibaldi E., Tulli F., Franchin C., Badini E., Messina M., 2004. High levels of vegetable protein sources in feed formulation for sea bass: effects on growth and quality. Proc. Int. Conf. 
"Biotechnologies for quality" (S. Adams and J.A. Olafsen Eds.) Barcellona, Spain, October 20-23, EAS Special Publ. n. 34 : 787-788.

Tulli F., Franchin C., Tibaldi E., 2004. High levels of vegetable protein sources in feed formulation for sea bass: effects on growth and quality. Proc. Int. Conf. "Biotechnologies for quality" (S. Adams and J.A. Olafsen Eds.) Barcellona, Spain, October 20-23, EAS Special Publ. n. 34 : 757-758.

Todgham A.E., Anderson P.M., Wright P.A., 2001. Effects of exercise on nitrogen excretion, carbamoyl phosphate synthetase III activity and related urea cycle enzyme in muscle and liver tissues of juvenile rainbow trout (Oncorhynchus mykiss). Comp. Biochem. Physiol., A 129: 527-539.

Wilson R.P., 1973. Nitrogen metabolism in channel catfish, Ictalurus punctatus II. Evidence for an apparent incomplete urea cycle. Comp. Biochem. Physiol. B 46: 625-634.

Wright P.A. and Land M.D., 1998. Urea production and transport in teleost fishes. Comp. Biochem. Physiol. A 199: 47-54.

Wright P.A., Felskie, A., Anderson, P.M., 1995. Nitrogen excretion: three end products, many physiological roles. J. Exp. Biol. 198: 273-281. 
Table 1 Composition, proximate analysis and Essential Amino Acid Index (EAAI) of the experimental diets.

\begin{tabular}{|c|c|c|c|c|c|}
\hline & P1 & P2 & P3 & F1 & F2 \\
\hline Arginine (g/100g diet) & 1.6 & 3.0 & 4.0 & 3.0 & 4.0 \\
\hline \multicolumn{6}{|l|}{ Composition (g/kg diet) } \\
\hline Fish meal $70^{a}$ & & & & 380.0 & 380.0 \\
\hline Fish protein concentrate ${ }^{b}$ & 50.0 & 50.0 & 50.0 & 50.0 & 50.0 \\
\hline Corn Gluten ${ }^{c}$ & 140.0 & 140.0 & 140.0 & 138.3 & 138.3 \\
\hline Amygluten 110 & 293.8 & 293.8 & 293.8 & & \\
\hline Extruded Wheat & 158.6 & 158.6 & 158.6 & 250.0 & 250.0 \\
\hline Cod liver oil ${ }^{a}$ & 152.4 & 152.4 & 152.4 & 76.6 & 76.6 \\
\hline Cellulose $^{d}$ & & 31.2 & 53.2 & 14.6 & 36.6 \\
\hline CaHPO4.2H20 (18\%P) & 55.2 & 55.2 & 55.2 & 10.9 & 10.9 \\
\hline Basal mix ${ }^{1}$ & 40.15 & 40.15 & 40.15 & 40.15 & 40.15 \\
\hline L-arg & 2.3 & 16.5 & 26.5 & 1.9 & 11.9 \\
\hline L-lys & 10.3 & 10.3 & 10.3 & & \\
\hline L-sulphur AA & 1.4 & 1.4 & 1.4 & & \\
\hline L-glu & 95.9 & 50.4 & 18.4 & 37.6 & 5.6 \\
\hline \multicolumn{6}{|l|}{ Proximate analysis (\% diet) } \\
\hline Moisture & 6.3 & 6.0 & 6.6 & 7.9 & 7.7 \\
\hline Crude protein & 43.9 & 43.5 & 43.5 & 43.7 & 43.3 \\
\hline Crude Lipid & 17.0 & 17.2 & 16.8 & 13.0 & 12.8 \\
\hline Fiber & 1.9 & 4.0 & 5.5 & 3.0 & 4.6 \\
\hline Ash & 6.6 & 6.5 & 6.4 & 8.2 & 8.2 \\
\hline$E A A$ Index & 63.1 & 68.7 & 70.2 & 100.8 & 103.2 \\
\hline
\end{tabular}

${ }^{\mathrm{a} L a}$ lorientaise des produits de la pêche, Lorient, France

${ }^{\mathrm{b}} \mathrm{CPSP} \mathrm{G}$, Sopropêche, France

${ }^{\mathrm{c}}$ Roquette frères, Lestrem, France

${ }_{1}^{d}$ Arbocel B00, J. Rettenmaier \& Söhne, Deutshland

${ }^{1}$ Common ingredients $\left(\mathrm{g} / \mathrm{kg}\right.$ diet): vitamin $\mathrm{mix}^{2}: 10$; mineral $\mathrm{mix}^{3}: 10$; guargel (Louis François, St Maur, France): 10; Agar (Louis François, St Maur, France): 10; ethoxyquine (Sigma E8260, St Quentin Fallavier, France): 0.15 . 'Supplied the following: as per NRC, 1993 (to provide $\mathrm{mg} / \mathrm{kg}$ diet): retinyl acetate $(250,000$ $\mathrm{U} / \mathrm{g}), 0.5$; cholecalciferol $(240,000 \mathrm{U} / \mathrm{g}), 2.4$; ascorbyl phosphate $(25 \%): 200$; tocopheryl acetate, 50 ; menadione, 10; thiamin, 1; riboflavin, 4; pyridoxine, 3; Ca-pantothenate, 20; vitamin $\mathrm{B}_{12}, 0.01$; niacin, 10; biotin, 0.15; folic acid, 1; choline, 1000; inositol, 300. ${ }^{3}$ Supplied the following (to provide $\mathrm{mg} / \mathrm{kg}$ diet, except as noted): magnesium carbonate, $1,24 \mathrm{~g}$; calcium carbonate, 2,15g; potassium chloride, $0.90 \mathrm{~g}$; sodium 
chloride, $0.40 \mathrm{~g}$; potassium iodide, 0.4; copper sulphate, 30; cobalt sulphate, 0.2 ; ferric sulphate, $0.20 \mathrm{~g}$; manganese sulphate, 30; zinc sulphate, 40; dibasic calcium phosphate, $5 \mathrm{~g}$; sodium fluoride: 10. 
Table 2 Voluntary feed intake, nitrogen and arginine intakes, final weights and feed and protein efficiency of juvenile sea bass fed the experimental diets for 72 days. Average initial weight: $8.4 \pm 0.07$.

\begin{tabular}{lrrrrrr}
\hline & P1 & P2 & P3 & F1 & F2 & $\begin{array}{r}\text { MSE } \\
\text { d.f. }=10\end{array}$ \\
& & & & & & \\
\hline Feed intake (g d.m./kg ABW/d) & 21.80 & 21.45 & 22.12 & 21.30 & 21.68 & 0.770 \\
$\mathrm{~N}^{*} 6.25$ intake (g/kg ABW/d) & 10.90 & 10.56 & 11.03 & 10.97 & 11.02 & 0.192 \\
Arginine intake (mg/kg ABW/d) & $397.4^{\mathrm{c}}$ & $728.2^{\mathrm{D}}$ & $1014.2^{\mathrm{a}}$ & $753.3^{\mathrm{D}}$ & $1017.7^{\mathrm{a}}$ & 1070.812 \\
Final weight (g) & $28.13^{\mathrm{C}}$ & $33.70^{\mathrm{D}}$ & $31.00^{\mathrm{D}}$ & $38.57^{\mathrm{a}}$ & $39.03^{\mathrm{a}}$ & 2.466 \\
FE $^{1}$ & $0.64^{\mathrm{D}}$ & $0.73^{\mathrm{a}}$ & $0.67^{\mathrm{D}}$ & $0.77^{\mathrm{a}}$ & $0.76^{\mathrm{a}}$ & $7.26 \mathrm{E}-04$ \\
PER $^{2}$ & $1.46^{\mathrm{D}}$ & $1.68^{\mathrm{a}}$ & $1.58^{\mathrm{D}}$ & $1.76^{\mathrm{a}}$ & $1.75^{\mathrm{a}}$ & $3.74 \mathrm{E}-03$ \\
\hline
\end{tabular}

Row means not sharing the same letters differ significantly, $P<0.05$

${ }^{1}$ Feed efficiency $=$ weight gain $/$ dry feed intake

${ }^{2}$ Protein efficiency ratio $=$ weight gain $/$ protein intake 
Table 3 Whole body crude protein and lipid levels ( $\mathrm{g} / 100 \mathrm{~g}$ tissue), nitrogen gain and retention and hepatosomatic $(\mathrm{HSI})$ and mesenteric fat (MF) indices of juvenile sea bass fed the experimental diets for 72 days.

\begin{tabular}{|c|c|c|c|c|c|c|}
\hline & P1 & P2 & P3 & $\mathbf{F 1}$ & F2 & $\begin{array}{l}\text { MSE } \\
\mathrm{df}=10\end{array}$ \\
\hline WB crude protein ' $(\%)$ & $16.07^{\circ}$ & $16.79^{\mathrm{ab}}$ & $17.52^{a}$ & $17.43^{\mathrm{a}}$ & $16.77^{\mathrm{ab}}$ & 0.144 \\
\hline WB total lipid ' (\%) & 8.19 & 7.97 & 7.93 & 7.97 & 7.70 & 0.007 \\
\hline Lipid gain (g/kg ABW/d) & 1.33 & 1.43 & 1.37 & 1.51 & 1.45 & 0.0068 \\
\hline $\mathrm{N}$ gain $(\mathrm{mg} / \mathrm{kg} \mathrm{ABW/d})$ & $383^{c}$ & $437^{\mathrm{DC}}$ & $466^{\mathrm{D}}$ & $512^{\mathrm{a}}$ & $486^{\mathrm{ab}}$ & 447.326 \\
\hline $\mathrm{NR} / \mathrm{NI}^{2}(\%)$ & $23.1^{\mathrm{C}}$ & $27.4^{\mathrm{D}}$ & $28.2^{\mathrm{D}}$ & $31.6^{a}$ & $29.8^{\mathrm{ab}}$ & 1.732 \\
\hline $\mathrm{HSI}^{3,4}(\%)$ & $2.75^{\mathrm{a}}$ & $2.22^{\mathrm{D}}$ & $1.88^{\mathrm{C}}$ & $2.84^{\mathrm{a}}$ & $2.27^{\mathrm{D}}$ & 0.111 \\
\hline $\mathrm{MF}^{3,5}(\%)$ & $6.85^{\mathrm{DC}}$ & $8.44^{\mathrm{a}}$ & $6.52^{\mathrm{c}}$ & $7.58^{\mathrm{ab}}$ & $7.84^{\mathrm{ab}}$ & 1.877 \\
\hline
\end{tabular}

Row means not sharing the same letters differ significantly, $p<0.05$

${ }^{1}$ Values represent the mean of 3 pooled samples per diet.

${ }^{2} \mathrm{NR} / \mathrm{NI}=$ nitrogen retained in fish whole body / nitrogen intake

${ }^{3}$ Values represent the mean of 3 samples per diet.

${ }^{4}$ Hepatosomatic index $=($ liver weight $\times 100) /($ body weight $)$.

${ }^{5}$ Mesenteric fat $=($ Mesenteric fat weight $x 100) /($ body weight $)$. 
Table 4: $k_{m}$ and $V_{\max }$ of ARG, OCT and GDH in sea bass liver extracts.

Values are mean \pm SD of 5 individual samples.

\begin{tabular}{ccc}
\hline ENZYME & $\mathbf{V}_{\max }$ & $\mathbf{K}_{\mathbf{m}}$ \\
\hline ARG & 19.72 & $3.73 \pm 0.42$ \\
OCT & 2.53 & $0.15 \pm 0.08$ \\
GDH & 11.24 & $2.91 \pm 0.70$
\end{tabular}


Table 5: Plasma ammonia, urea and uric acid concentrations 6-h after a single meal and just before the next meal $(0 \mathrm{~h})$ in sea bass, irrespective of the diet being fed.

\begin{tabular}{|c|c|c|c|c|}
\hline & $6 \mathrm{~h}$ & Oh & d.f. & ESM \\
\hline $\mathrm{NH}_{3}(\mathrm{mmol} / \mathrm{l})$ & $0.37^{a}$ & $0.18^{b}$ & 142 & 11.228 \\
\hline Urea (mmol/l) & $2.56^{\mathrm{a}}$ & $1.70^{\mathrm{b}}$ & 149 & 0.359 \\
\hline Uric acid (mmol/l) & 0.19 & 0.18 & 149 & 3.27E-04 \\
\hline
\end{tabular}


Table 6 Nitrogen and arginine intakes, daily nitrogen excretion rates and ratios in sea bass fed the test diets.

\begin{tabular}{|c|c|c|c|c|c|c|}
\hline & P1 & P2 & P3 & $\mathbf{F 1}$ & F2 & $\begin{array}{l}\text { MSE } \\
\mathrm{df}=15\end{array}$ \\
\hline N intake $(\mathrm{m} \mathrm{g} / \mathrm{kg} \mathrm{ABW} / \mathrm{d})$ & 602 & 647 & 644 & 649 & 615 & 8838.2 \\
\hline Arginine intake (mg/kg ABW/d) & $136^{\mathrm{C}}$ & $277^{b}$ & $370^{a}$ & $281^{b}$ & $353^{a}$ & 755.8 \\
\hline TAN excretion (mg/kg ABW/d) & 244 & 243 & 234 & 225 & 211 & 2341.9 \\
\hline Urea-N excretion (mg/kg ABW/d) & $22^{b}$ & $41^{a}$ & $55^{a}$ & $50^{a}$ & $56^{a}$ & 99.7 \\
\hline Urea-N / (TAN + urea-N) (\%) & $8.2^{c}$ & $13.8^{b}$ & $18.1^{a b}$ & $18.4^{a b}$ & $21.0^{a}$ & 10.3 \\
\hline TAN/NI(\%) & $40.4^{a}$ & $39.6^{a}$ & $38.1^{a b}$ & $34.6^{b}$ & $34.3^{b}$ & 8.6 \\
\hline Urea-N/NI (\%) & $3.6^{c}$ & $6.4^{b}$ & $8.5^{a b}$ & $7.7^{a b}$ & $9.2^{a}$ & 2.7 \\
\hline$(\mathrm{TAN}+$ urea-N) / NI (\%) & 44.1 & 45.9 & 46.5 & 42.4 & 43.5 & 11.1 \\
\hline
\end{tabular}

Row means not sharing the same letters differ significantly, $p<0.05$ 
Figure 1 Pre-feeding and 6-h post-feeding liver arginase activity in seabass fed the experimental diets.
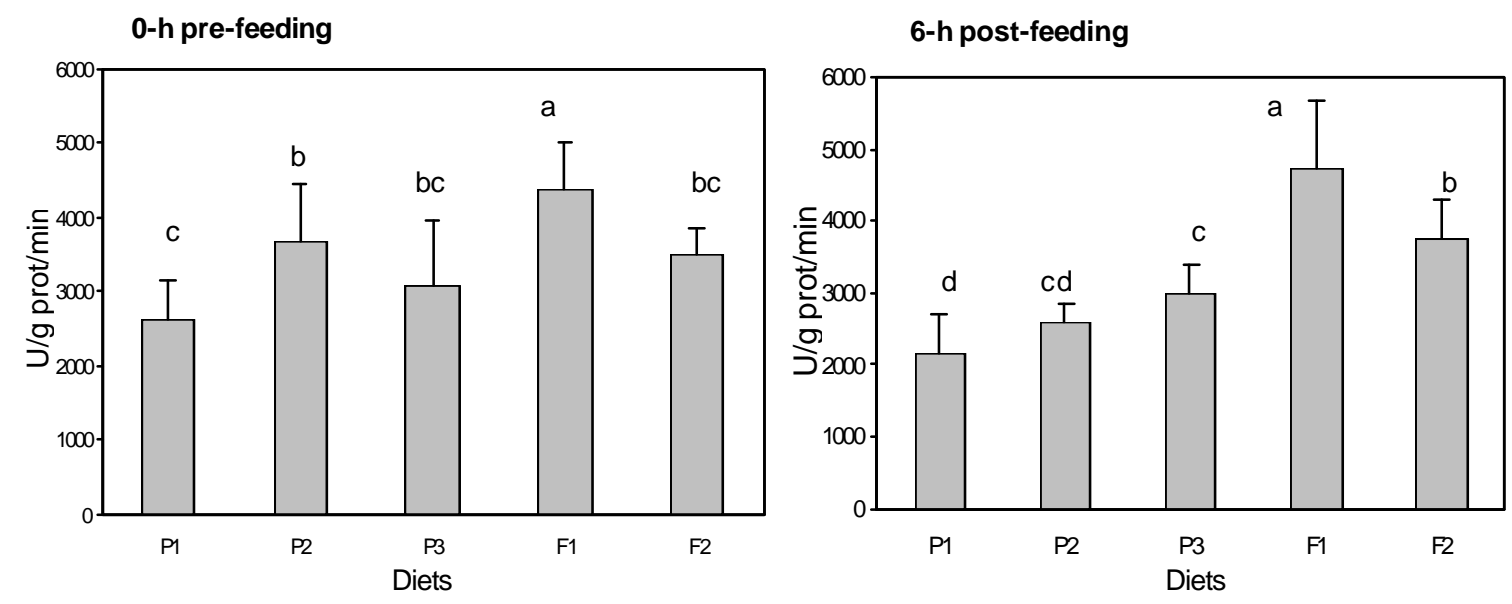
Figure 2 Pre-feeding and 6-h post-feeding liver OCT activity in seabass fed the experimental diets.
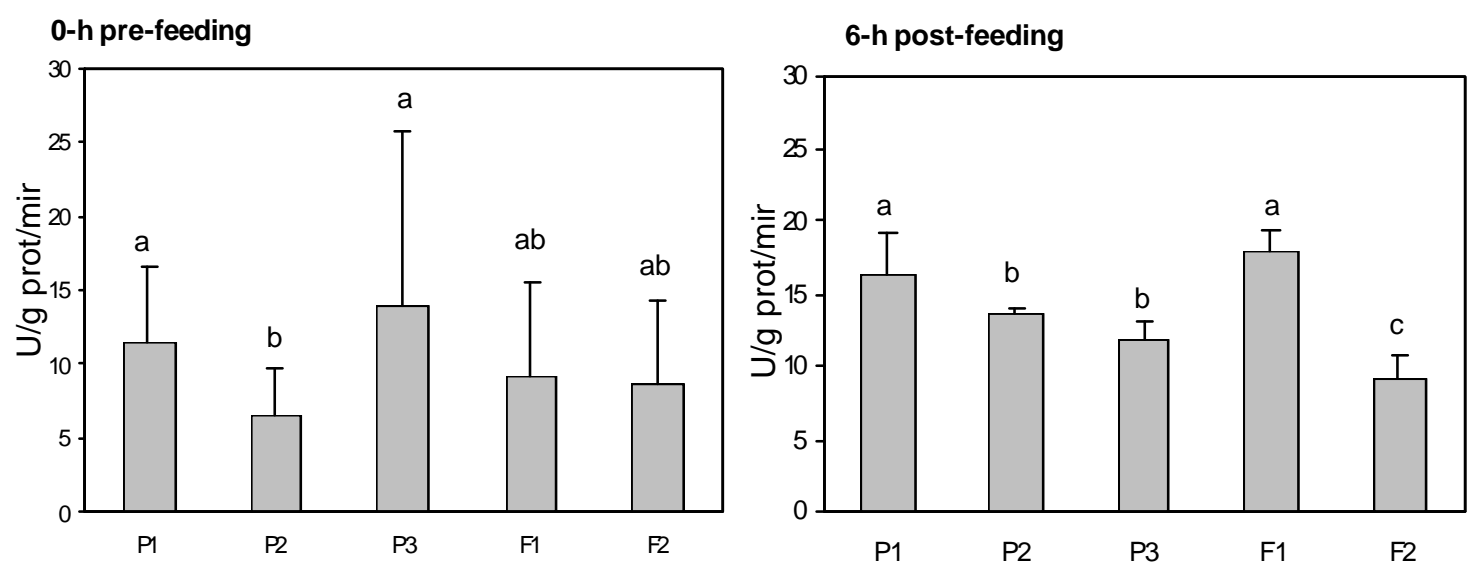
Figure 3 Pre-feeding and 6-h post-feeding liver GDH activity in seabass fed the experimental diets.
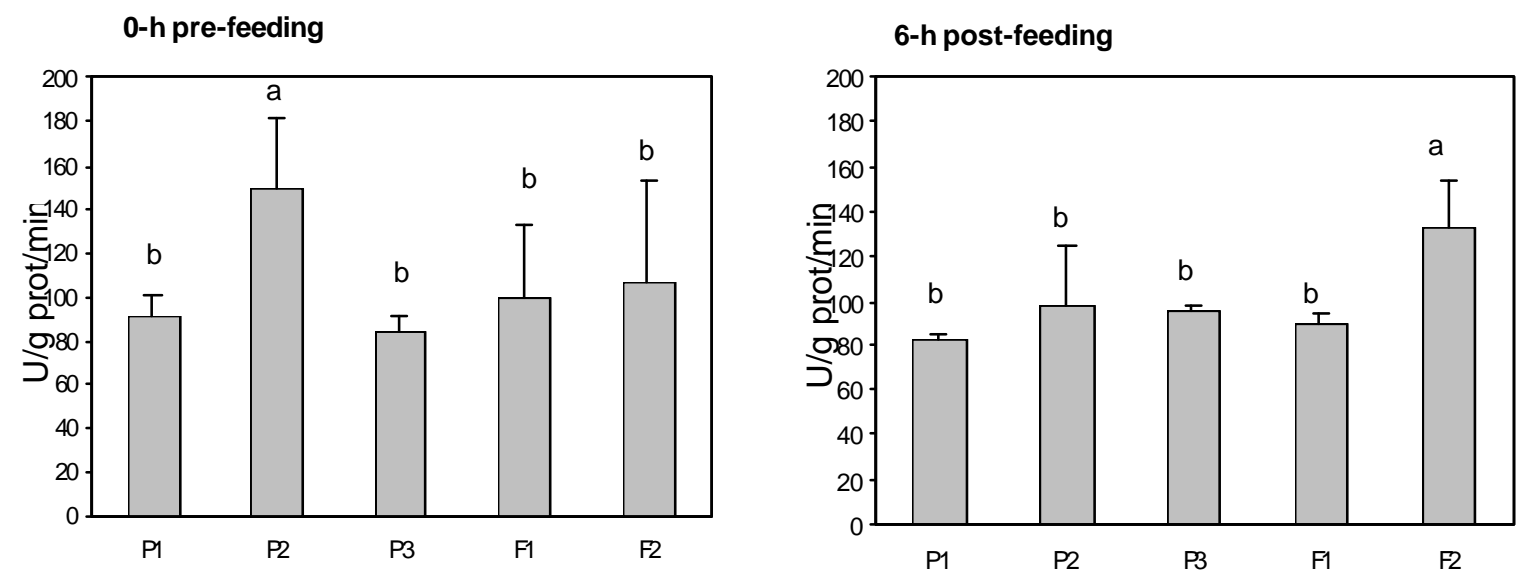
Figure 4: Pre and 6-h post-feeding plasma ammonia levels in seabass fed the experimental diets.

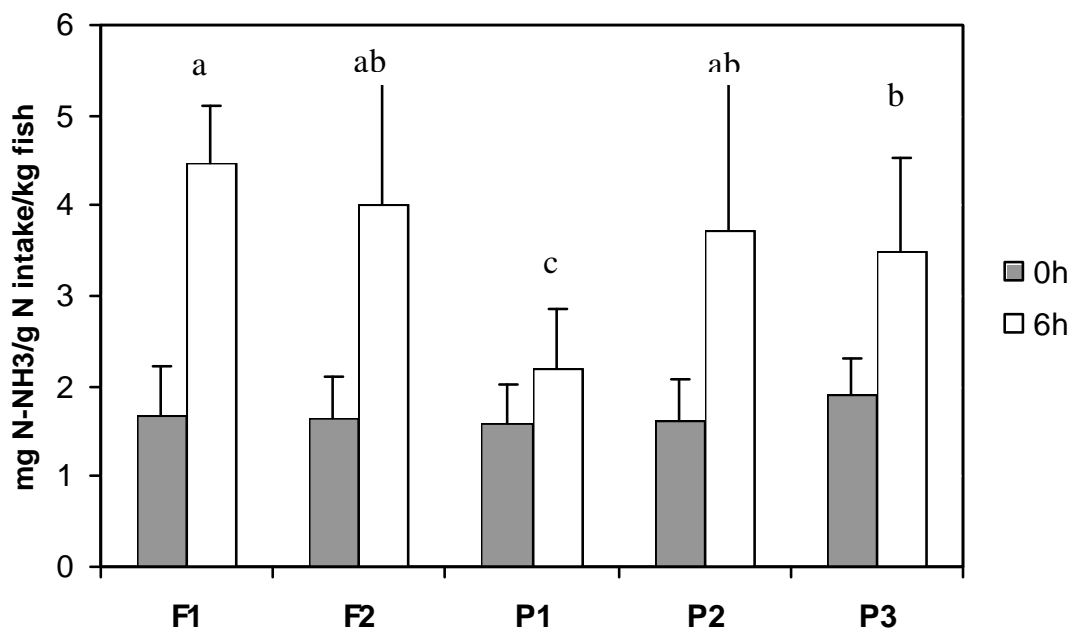


Figure 5 : Pre and 6-h post-feeding plasma urea levels in seabass fed the experimental diets.

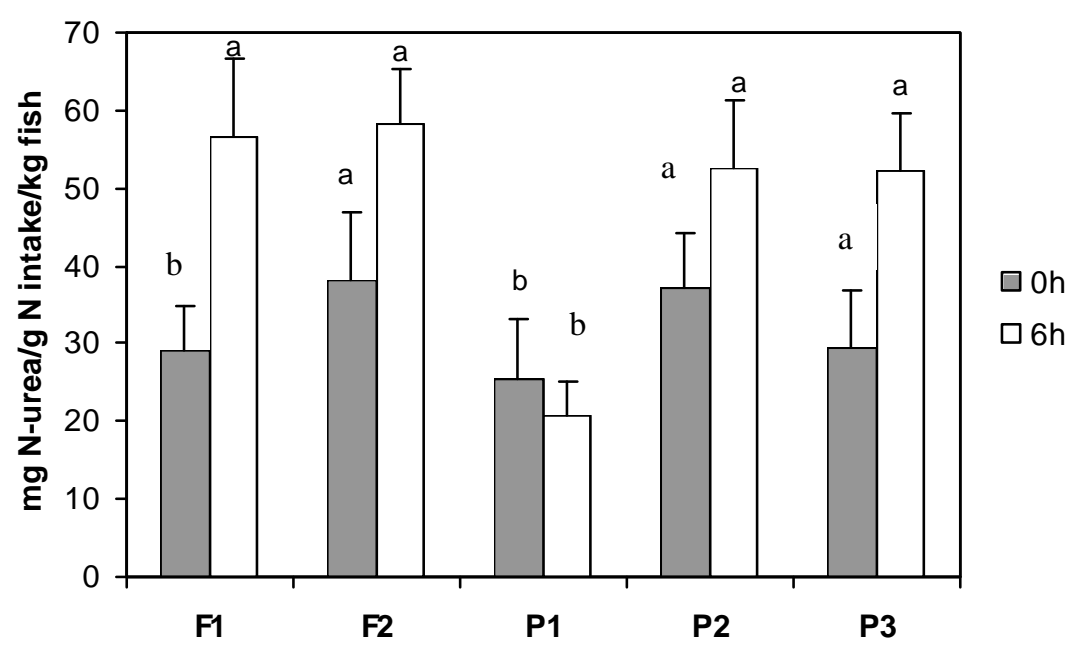


Figure 6 24-h pattern of ammonia- $\mathrm{N}$ excretion following a single meal in juvenile seabass fed the experimental diets. Values are means \pm st. dev. of duplicate measurements in duplicate tanks.

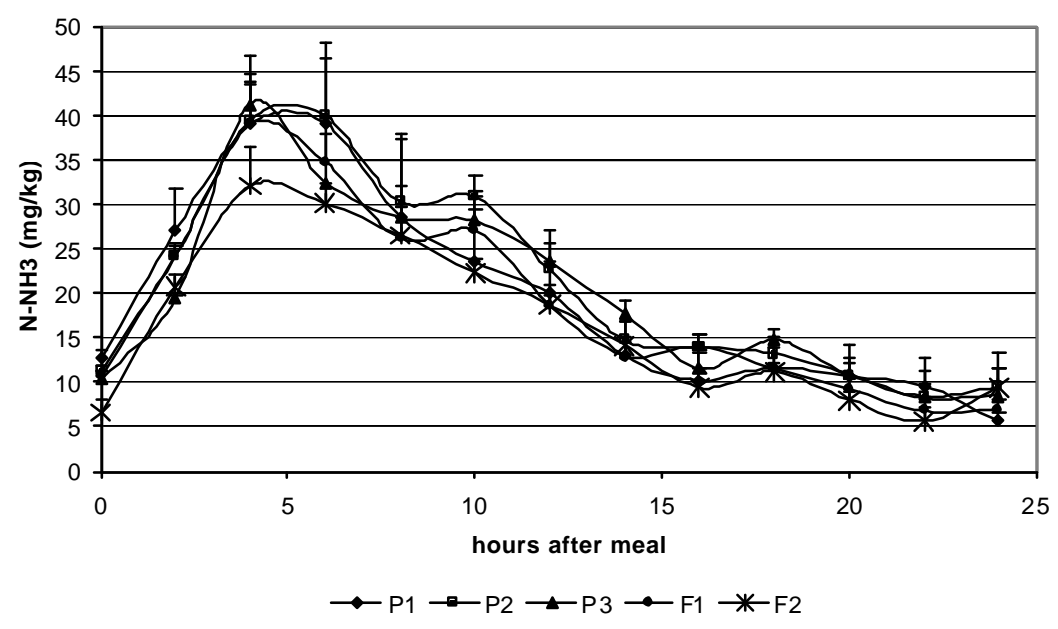


Figure 724 -h pattern of urea- $\mathrm{N}$ excretion following a single meal in juvenile seabass fed the experimental diets. Values are means \pm st. dev. of duplicate measurements in duplicate tanks.

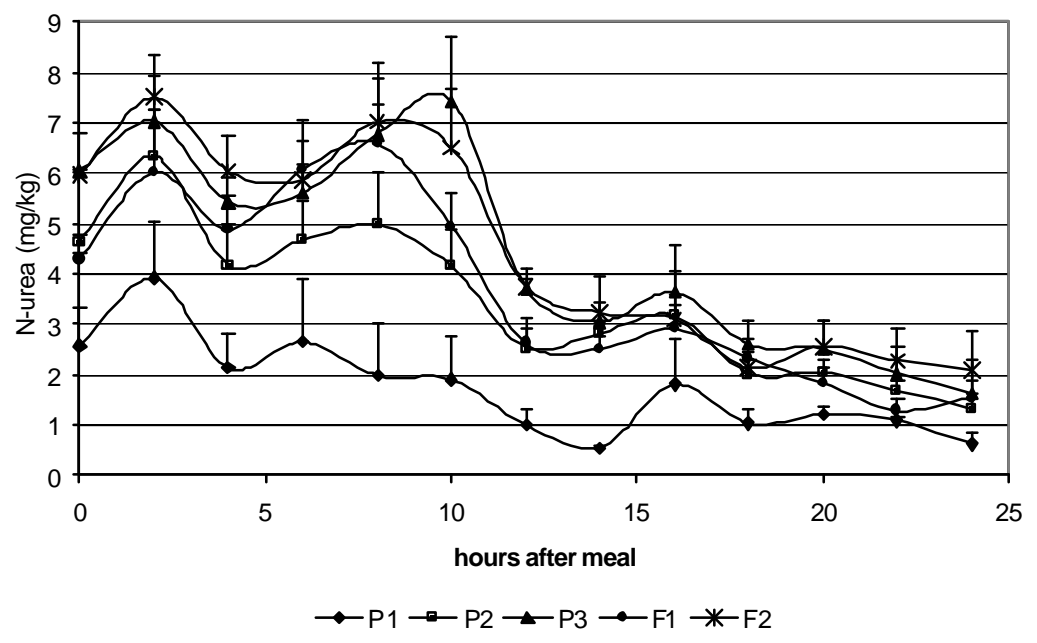


Figure 8 Relationship between arginine intake and liver arginase activity (umol/g/min) and urea $\mathrm{N}$ excretion $(\mathrm{mg} / \mathrm{kg} / \mathrm{d})$ in juvenile sea bass fed the experimental diets.

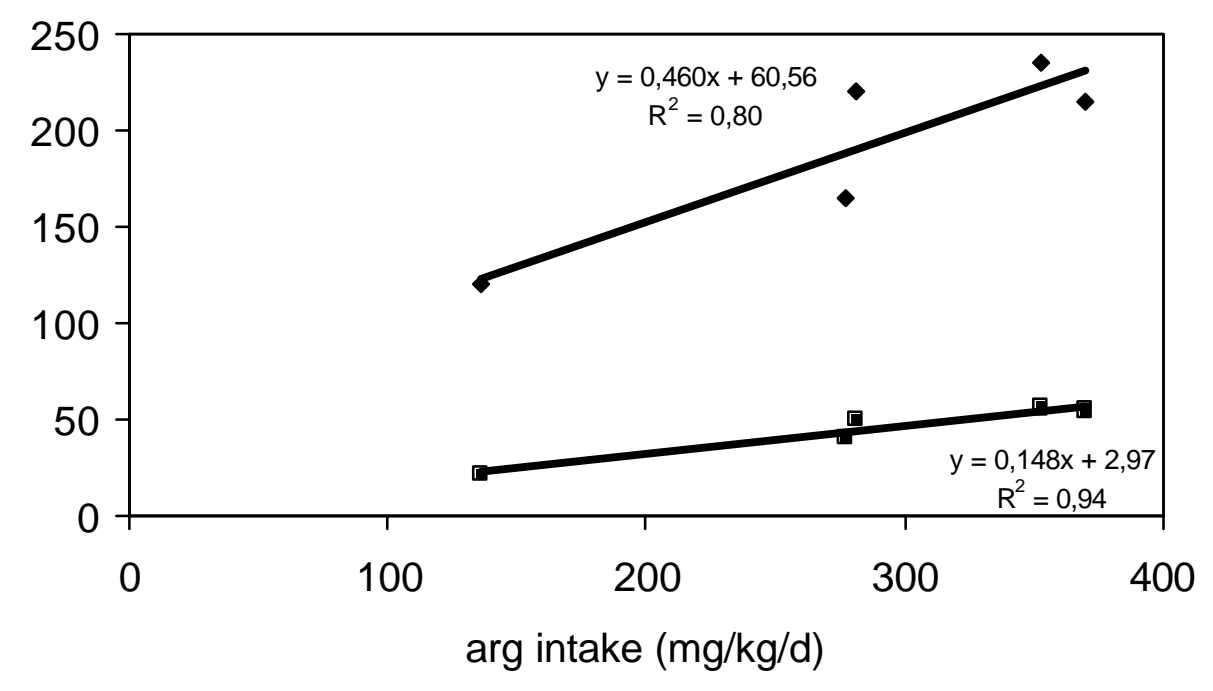

- ARGase activity $\approx \mathrm{N}$-urea excretion 
Figure 8 Relationship between liver arginase activity and urea $\mathrm{N}$ excretion (a) and between urea excretion and arginine intake (b) in juvenile sea bass fed the experimental diets
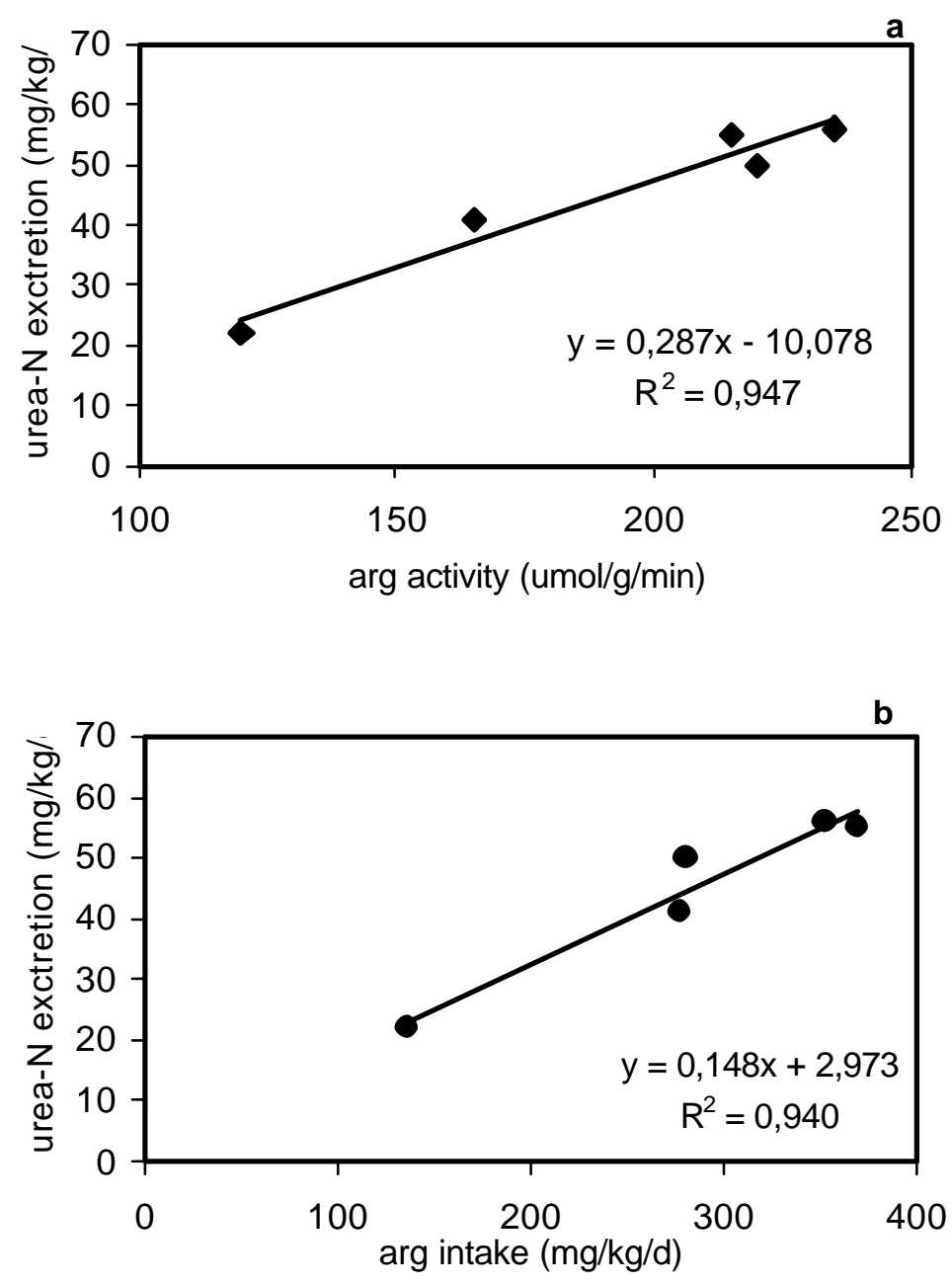